\title{
A Test Method of Sagging of Paint $\underset{607}{6067.613 .753}$
}

\author{
Hiroshi Makishima, Tsunehiko Toyoda \\ and Akitada Goto \\ Dainippon Toryo Co., Ltd.*
}

\begin{abstract}
The degree of sagging of paints during the process of spraying depends on the colour even if the paint compositions are the same otherwise, since the flow properties as well as hiding power are affected by the colour. Although a number of test methods of the degree of sagging have been reported, none of these appears to be satisfactory. In the present paper a new quantitative method was investigated, which provided very practical results. The results were in good accord with the results theoretically calculated from changes in wet film thickness, specific gravity, apparent viscosity and thixotropic recovery during solvent evaporation.

Paints were sprayed at a constant speed on the panels laid on a drum which rotated at a specified speed. By changing the rotating speed of the drum, film thickness was changed. Thereby the critical film thickness above which the sagging appeared was determined.

The extent of sagging was greater, the greater the apparent viscosity drop at high rate of shear was, and the slower the viscosity recovery was. The results which were obtained with the conventional applicator method did not agree with the results which were obtained with the above method. In the former method the solvent content immediately after spraying, thixotropic breakdown, its recovery and the wettability of new surfaces are not playing parts.
\end{abstract}

* Daito-cho, Tsurumi-ku, Yokohama 


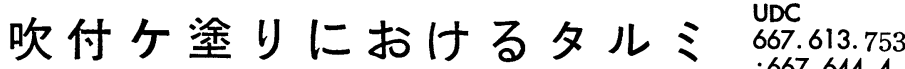

牧島 博*.豊田常彦*・後藤昭忠*

要

旨

塗料を吹付ヶ塗装したときのタルミの難易を定量的に判定する試験法について検討した。

この結果, 塗料流出量一定下で被塗物を回転させて吹付ヶ塗装し, 回転速度を変えることに より付着膜厚を変え, タルミの難易を比較する方法が最も実際に近い結果を与兄ることがわか った。また, この結果は, 溶剤の蒸発による膜厚, 比重, 粘度の変化や, チキソトロピーによ る見掛け粘度の経時変化を考慮した理論計算との結果とも一致した。

一方, 従来広く用いられているアプリケーターによるタルミの試験結果を, そのまま吹付ケ 塗装の場合の判定に適応することは問題があり, 付着時の溶剤濃度, チキソトロピーによる見 掛け粘度の変化，新しい面の湿潤などを考慮しなけれならない。

\section{1. 緒言}

塗装後, 乾燥過程で発生する欠陥の一つにタルミ (running または sagging) の現象がある。この現象に 関しては比較的古くから研究され，塗料がニュートン流 体の場合には R. J. Blackinton ${ }^{1)}$ とよりタルミに関する 理論式が導かれている。また，W.K. Asbeck ${ }^{2)}$ は非二 ニートン流体の場合のタルミについて補正項を導入した 理論式を導いた。

これらの理論式は, いずれも塗膜形成過程での溶剤の 蒸発やこれに伴う塗膜の粘度, 膜厚, 比重の経時変化が ほとんで無視できると仮定した場合に成立するものであ る。実際の塗膜で発生するタルミ現象では，これらの経 時変化量を考慮し，さらにチキントロピー性についての 考慮も加光て解析しなければならない。現在のところこ れらすべてを考慮した解析は行なわれていない。

また, タルミの試験法についても各種の試験法が考案 検討されてきた。これらは, アプリケーターで塗装した 直後の塗膜の中間をある幅にかき取り, 垂直に立ててカ ット部へのタルミを試験する T.C. Patton ${ }^{3)}$ の方法や, 特 殊なクシ型アプリケーター (Sag Index) で塗装し垂直 面のタルミを観察する W.W. Reynolds ${ }^{4)}$ の方法, 一定 膜厚に塗装した時のタルミの長さで比較する H.E. Han$\operatorname{cock}^{5)}$ らの方法などがある。これらはいずれるアプリケ ーターを使ったタルミ試験法であるが，吹付ヶ塗装にお

昭 42 . 8. 8 受理

*大日本塗料株式会社中央研究所

横浜市鶴見区大東町 $12-1$
けるタルミの判定に, そのまま使用できるかどうかにつ いては疑問がある。

また吹付ケ塗装によるタルミの試験法については, 付 着塗膜の不揮発分, 膜厚などが不明確であり適切な試験 方法がない。

以上のよ $な$ 背景から吹付ケ塗装される塗料のタルミ 現象について，その試験方法の検討を行ない，吹付ヶ塗 装におけるタルミの難易を理論式から求めることを試み た。

\section{2. 理論}

塗料がニュートン流体で溶剤の蒸発や粘度変化など環 境条件の変化が無視できる場合には, タルミの速度に関 しては R. J. Blackinton'1)により理論式が導かれている。

$$
V=\frac{\rho g x^{2}}{2 \eta}
$$

$V:$ 塗膜表面のタルミの速度

$x$ : ウエット膜厚

$\rho:$ 塗料の比重 $\eta:$ 塗膜塗料の粘度 実際には塗料は溶剤の蒸発によって比重, 膜厚, 粘度な ぞが経時変化する。さらに塗料が非ニュートン性のとき は見掛け粘度がズリ速度に依存し, 取り分けチキソトロ ピー性のあるとさは時間依存性も加わる。このためタル ミの速度は時間がたつに従がって変化する。

式(1)に和いて塗付け直後からある時間（ $t$ 分）後の塗 膜の比重, 膜厚, 見掛壮粘度をそれぞれ, $\rho_{t}, x_{t}, \eta_{t}$ とす ると, この時の塗膜表面の流下速度 $V_{t}$ は式 $(2)$ となる。

$$
V_{t}=\frac{\rho_{t} g x_{t}^{2}}{2 \eta_{t}}
$$


$\rho_{t}, x_{t}, \eta_{t}$ を各時間において測定し， $V_{t}$ を時間の関数と して求める。この $V_{t}$ を積分して付着直後からタルミが 止まるまでの全タルミ距離を求めれば，その距離の大小 をもって各塗料間のタルミの難易を比較することができ る。

\section{3. 実 験}

\section{$3 \cdot 1$ 試 料}

長油性フタル酸ワニスにより, チタン白, ベンガラ, アゾ系黄, フタロシアニンブルー，の各顔料をそれぞれ 分散練合し供試塗料とした。

希釈用シンナーはミネラルスピリット主体の炭化水素 系混合溶剂とした。

各塗料は塗装に当たって粘度を一定に調整した。アプ リケーター塗装に打ける各塗料の粘度は, $76 \mathrm{KU}, 68 \mathrm{KU}$, $60 \mathrm{KU}$ 值にそれぞれ希釉した。また吹付ケ塗装のとき の粘度はフォードカップ No. 4 にて $45 \pm 1$ 秒に希釈し た。ただしアり゙系黄, フタロシアニンブルーの塗料はチ キソトロピー性が著しいため，調整時には十分かきまぜ た後の粘度を測定した。

\section{$3 \cdot 2$ タルミ試験方法}

(a) タルミ試験用アプリケーターによる試験

$75 ， 100 ， 150 ， 200 ， 250 \mu$ のすき間を一本のアプリ ケーターに切り込んだクシ型アプリケーターを使い, ミガキ板ガラス上に一度に各膜厚の塗膜を塗り付け, 垂直に保らどの膜厚の塗膜からタルミが起こるかを比 較する。

（b）吹付ヶ塗りによる未塗装部分へのタルミ試験 試験片は軟鋼板にめらかじめ試料と同じフタル酸樹 脂塗料を塗装乾燥したものとする。

試験片の一端を紙テープでマスクし吹付ケ塗装用に 調整した塗料を吹付ヶ塗装する。このとき被塗物とス プレーガン (Wider 61, 口径 $1.2 \mathrm{~mm}$ ) との距離, 吹 付流出量を一定に調節する。吹付ヶ後直ちにマスク をはずし未塗装部分を下方にして垂直に保ら，塗膜の 未塗装部分へのタルミを観察する。吹付け直後の塗膜 の不揮発分および塗装直後のウェット膜厚は同時に塗 装した別の試験片の付着重量, 塗布面績, 塗料の比重, 乾燥膜重量より計算により求めた。

(c) 吹付ケ塗りによる塗装面内でのタルミ試験

実際の塗装現場で起こるタルミ現象に近い状態で試 験する方法として以下のような試験装置を試作した。 モーターによって回転するドラム（回転軸は垂直方向） に試験片を取り付け試験片から $30 \mathrm{~cm}$ の位置にスプレ ーガンを設置する。吹付ケ時の流出量は各塗料間で差
のないように流出バルブのみによって調整し，ドラム を回転させて吹付ケ塗装する。吹付け流出量, ドラム 回転速度が一定ならば, 付着直後のウエット膜厚は霧 化状態下での蒸発量の違いにより変わるが，本実験の よ5に同一系統の塗料の場合にはその差は小さいので ウェット膜厚は泀とえど等しくなる。回転速度を変え て付着膜厚を変え, タルミの起こる限界の回転速度を 求め, 各塗料のタルミの起こる限界回転速度を比ベタ ルミやすさを比較する。

\section{$3 \cdot 3$ 流動特性測定}

タルミ現象を考察するとき, 吹付ヶ塗装後の塗膜の見 掛け粘度を知ることが必要である。高濃度ではほとんど の塗料が非ニュートン性であるため見掛け粘度はズリ速 度に依存する。タルミ現象のズリ速度は $10^{-1} \mathrm{sec}^{-1}$ の才 ーダーであるといわれているが，タルミは動的現象であ るためズリ速度も始めと終りでは異なる。

本実験では共軸二重円筒型回転粘度計により, ズリ速 度 $0.55 \mathrm{sec}^{-1}$ にて見掛け粘度を測定した。さらにチキソ トロピー性を示す試料についてはスターラーにて数分間 $2000 \mathrm{rpm}$ の回転速度でかきまぜ，すばやく粘度計用カ ップに移して静置し $D=0.55 \mathrm{sec}^{-1}$ のズリ速度に括ける 見掛け粘度を測定した。この測定までの静置時間を変え て見掛壮粘度の回復の速さを求めた。

\section{4. 結果および考察}

\section{$4 \cdot 1$ アプリケーター塗装によるタルミ試験}

アプリケーター塗装によりタルミを判定する場合, 塗 装膜厚の再現性が問題となる。同一塗料を塗装した場 合，並びに色の異なる塗料を同一粘度に調整して塗装し た場合の塗布直後の膜厚の再現性について検討した。

6 ミルアプリケーターにより, フタル酸樹脂エナメル フタロシアニンブルー（チキソトロピー性を有する）に つき,塗装前にかきまぜ（2000 rpm，3 分間）て塗装した 場合と一昼夜静置状態の塗料をかきまぜずに塗装した場 合について比較した。また, $59 \mathrm{KU}$ 值に調整したフタル 酸樹脂エナメルチタン白(チキソトロピー性なし)と同フ タロシアニンブルーにつき，かきまぜた試料を 6 ミルア プリケーターで塗装したときのウエット膜厚を比較した。

それぞれ,塗布直後の重量測定より膜厚を求めた結果， 前者, 後者とも測定值は平均值 $\pm 4 \%$ 以内であり, 検定の 結果それぞれ二者の平均值間の差はないことを確認した。

以上確認後, タルミ試験用アプリケーター（クシ型ア プリケーター）を使い，KU 值を同じ值に調整した各色 塗料を規定の方法により塗装, タルミ試験を行なった。 ただし有機系顔料の塗料ではチキソトロピー性があり, 
塗装前のかくはんの有無がタルミに大きく影響する6)の で，2000 rpm 3 分間かきまぜた塗料を試験供した。

結果を表-1 に示した。表中の数字は 0 がタルミの全 く起こらない場合であり, 以下数字が大きくなる順にタ ルミも多くなる。

試験結果から，同一 $\mathrm{KU}$ 值に調整した場合には無機系 顔料のチタン白やベンガラの塗料の方が有機系顔料のフ タロシアニンブルー，アゾ系黄の塗料よりタルミを起こ しやすい。しかし，この結果が吹付ヶ塗装比けるタル ミの難易と一致するかどうかが問題である。実際の吹付 け塗装では, 吹付ヶ前の粘度が等しい場合でも, 付着時 の塗膜の粘度が等しいといらことは少ない。付着直後の 濃度に相当する試料を各色ごとに調整してテストに供す ることが最良と思われるが，現実の実験としては繁雑と なってむずかしい。

\section{$4 \cdot 2$ 吹付ヶ塗装による未塗装部分へのタルミ試験}

吹付ケ粘度に希釈した塗料の不揮発分拉よびこれらの 各塗料を空気圧 $4 \mathrm{~kg} / \mathrm{cm}^{2}$, 塗料流出量 $70 \mathrm{cc} / \mathrm{min}$ で 30 $\mathrm{cm}$ の距離から吹付ヶ塗装した時の付着直後の塗膜の不 揮発分を表-2 に示した。また，これらの条件で吹付ら

表-1 フタル酸樹脂エナメル各色のアプリケーター法による タルミ試験結果

室温 $20^{\circ} \mathrm{C}, \mathrm{RH} 75 \%$

\begin{tabular}{|c|c|c|c|c|c|}
\hline & 㵆 料 種 類 & チタン白 & ベンガラ & $\begin{array}{l}\text { フタロシア } \\
\text { ニンブルー }\end{array}$ & アゾ系黄 \\
\hline \multirow{6}{*}{$76 \mathrm{KU}$} & 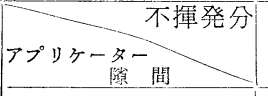 & $51.4 \%$ & $45.8 \%$ & $43.0 \%$ & $44.4 \%$ \\
\hline & $75 \mu$ & 0 & 0 & 0 & 0 \\
\hline & 100 & 1 & 1 & 0 & 0 \\
\hline & 150 & 2 & 2 & 1 & 1 \\
\hline & 200 & 3 & 3 & 2 & 2 \\
\hline & 250 & 3 & 3 & 3 & 3 \\
\hline \multirow{6}{*}{$68 \mathrm{KU}$} & 隍 間 不揮発分 & $50.5 \%$ & $45.4 \%$ & & \\
\hline & 75 & 0 & 0 & & \\
\hline & 100 & 1 & 1 & & \\
\hline & 150 & 2 & 3 & & \\
\hline & 200 & 4 & 4 & & \\
\hline & 250 & 5 & 5 & & \\
\hline \multirow{6}{*}{$60 \mathrm{KU}$} & 陌 間 不揮発分 & & & $39.6 \%$ & $41.3 \%$ \\
\hline & 75 & & & 0 & 0 \\
\hline & 100 & & & 0 & 1 \\
\hline & 150 & & & 2 & 2 \\
\hline & 200 & & & 3 & 3 \\
\hline & 250 & & & 3 & 3 \\
\hline
\end{tabular}

タルミなし $0<1<2<3$ タルミ多い
表-2 吹付ヶ直後のフタル酸樹脂エナメル塗膜 の不揮発分 (N.V.)

(塗料流出量 $70 \mathrm{cc} / \mathrm{min}$, 温度 $20^{\circ} \mathrm{C}$ )

\begin{tabular}{|c|c|c|}
\hline 料 & $\begin{array}{l}\text { 吹付け原液の } \\
\text { N.V. }\end{array}$ & $\begin{array}{l}\text { 吹付汀後付着 } \\
\text { 塗膜の N.V. }\end{array}$ \\
\hline チタン白 & $50.0 \%$ & $56.5 \%$ \\
\hline ベンガ & 42.9 & 45.2 \\
\hline $\begin{array}{l}\text { フ タ シ ア } \\
=\text { ンブル }\end{array}$ & 35.3 & 48.6 \\
\hline アゾ系黄 & 36.2 & 45.0 \\
\hline
\end{tabular}

塗装し，規定の方法によって未塗装部分へのタルミを調 べた結果を図-1，図-2 に示した。図-1 はフタル酸樹脂 エナメルチタン白の結果であり，横軸恃付着時のウエッ ト状態の膜厚を示し縦軸は付着時の塗料の不揮発分を示 している。図中の斜めの実線は各濃度でタルミが起こる 境界值を示し線の左上方はタルミが起こらず，左下方は タルミが起こることを表わす。図-2 は各塗料决 の図一の上5な結果より境界線を求め, それらをまとめ たものである。

付着值後の不揮発分の結果と図-2 の各濃度に抢汗る タルミの限界值とから付着直後のタルミの限界膜厚を求 め結果を表-3 に示した。

表-3 より，タルミを起こしやすい叙 料は限界膜厚の小さいチタン白およびべ ンガラの塗料であり，有機系顔料を使っ た塗料は無機系のものに比べてダルミを 起こし難い。このダルミの順位は前項の アプリケーターによるタルミ試験の結果 と比較的よく一致した。

本試験法と実際の塗装で起こるタルミ 現象との違いは, 本試験法では叙料が塗 膜下端に, ある量に達するまで流れ出さ ずにたまり，その後未塗装部分一流れ出 すのに対し，実際の塗装でのタルミは塗 装面内を流れてできる不均一膜厚のタル ミである。塗膜下端にある時間たまって いることは，その間に粘度の回復が考兑 られ，また未塗装部分へ流れるために新 しい面を始らす仕事量の必要などのた め, 塗装面内を流れるタルミの場合と条 件が異なる点がある。

\section{$4 \cdot 3$ 吹付ヶ塗装による塗装面内での タルミ試験}

各塗料をフォードカップ No. 4 で 45 \pm 1 秒に希积し, 吹付ヶ圧 $4 \mathrm{~kg} / \mathrm{cm}^{2}$, 塗 料流出量 $50 \mathrm{cc} / \mathrm{min}$ および $70 \mathrm{cc} / \mathrm{min}$ 


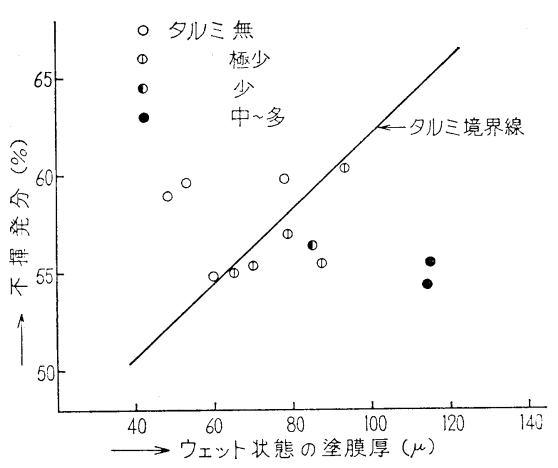

図-1 フタル酸樹脂エナメル・チタン白の吹付ヶ叙 りによる未塗装部分へのタルミ（温度 $20^{\circ} \mathrm{C}$ )

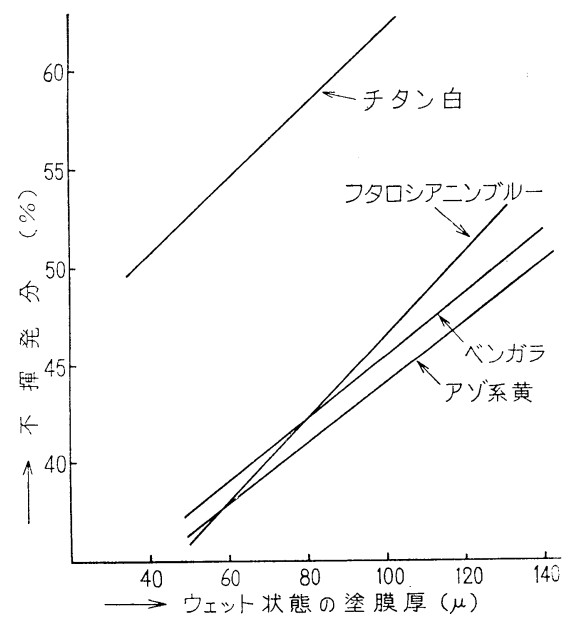

図-2 フタル酸樹脂エナメル各色の吹付ケ鍾りによ る未塗装部分へのタルミ境界線 (温度 $20^{\circ} \mathrm{C}$ )

表-3 吹付ヶ塗りに拈けるフタル酸樹脂エナメ ルのタルミ限界膜厚

(塗料流出量 $70 \mathrm{cc} / \mathrm{min}$, 温度 $20^{\circ} \mathrm{C}$ )

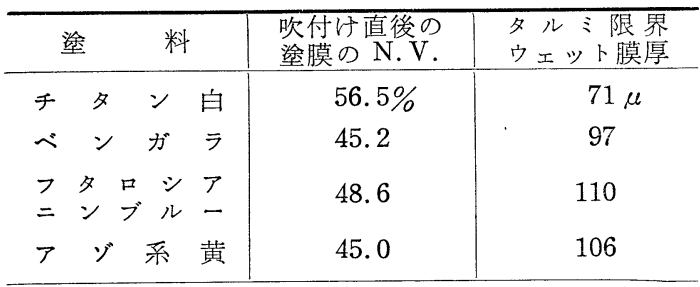

として，回転ドラムを使った規定のタルミ試験装置によ り実験を行なった。フタル酸樹脂エナメルチタン白につ いての結果を 図-3 に示した。図中の縦軸はドラムの回 転速度から求めたスプレーガン走行速度である。流出量 が一定のとき，この值が大きい方が付着膜厚は厚くなる。 図中の実線はタルミの限界線を示し, 線の上域はタルミ を起こし下域は起こさない。

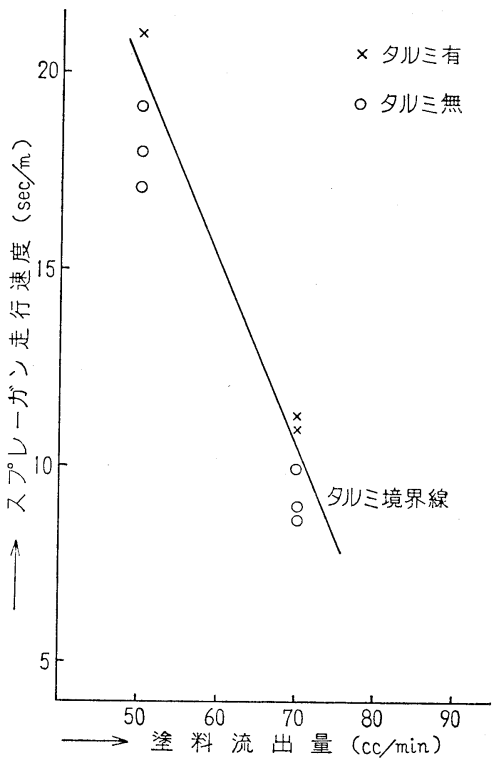

図-3フタル酸樹脂エナメル・チタン白の吹 付ヶ塗りによるタルミ境界線塗料流出量 とガン走行速度との関係 (温度 $20^{\circ} \mathrm{C}$ )

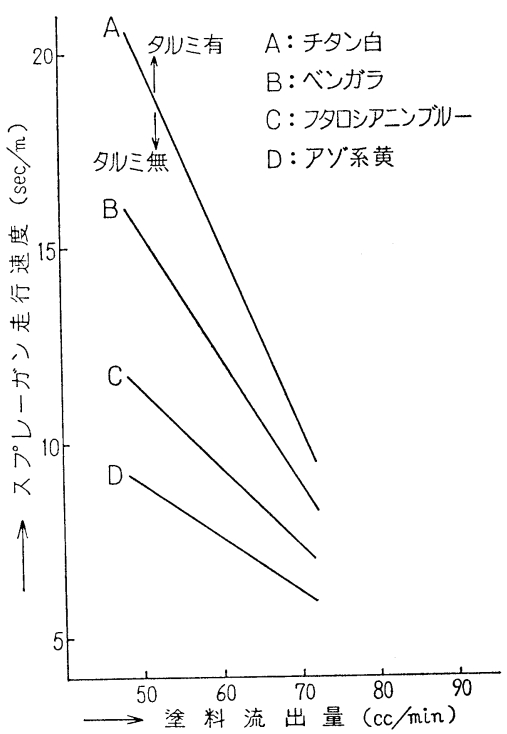

図-4フタル酸樹脂エナメル各色の吹付ケ 塗りによるタルミ境界線塗料流出量と ガン走行速度との関係 (温度 $20^{\circ} \mathrm{C}$ )

同様にして各塗料について求めた限界線をまとめた結 果を図-4 に示した。図-4 の結果より同一流出量での各 塗料間のタルミの難易を比較することができる。塗料流 出量 $50 \mathrm{cc} / \mathrm{min}, 70 \mathrm{cc} / \mathrm{min}$ のいずれの場合もタルミやす さの順序は変わらず, チタン白やベンガラは他の有機系: 
顔料の塗料に比べ，タルミの起こる限界のスプレーガン 走行速度は括そく, それだけ付着膜厚は厚くなってタル ミは起こりにくくなっている。この結果は前項までの試

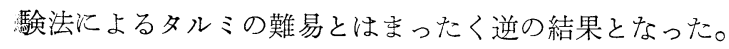

この原因は前項までの試験法が，未塗装部分へのタル ミを試験したため，ぬれ (wetting) の点から，岁る程 度境界部分に塗料がたまらなければ流れ出さず，また本 研究に使用した有機系顔料の塗料がいずれも著しいチキ ソトロピー性を示すため, 吹付ヶ時の高いズリ速度によ って低下した見掛け粘度はタルミ現象時の低ズリ速度下 ではその粘度を徐々に回復し，たまりの岁る場合は回復 時間が長くなって，見掛け粘度が增しタルミにくくな る。

一方, 本項の方法では, ぬれの仕事の点は塗装面内で のタルミをみるため問題とはならない。またチキソトロ ピー性による見掛け粘度の時間的変化も, 流れながら構 造回復するゆ兄, たまり現象による粘度の回復の問題は ない。これらの条件は実際の吹付塗装に抢汀るタルミ ね近いものである。

\section{$4 \cdot 4$ 理論式より求めたタルミの難易}

フタル酸樹脂エナメルチタン白拉よびアゾ系黄の塗料 について, 吹付ヶ塗装後の塗膜の蒸発速度を測定し, 塗 膜の不揮発分の経時変化を求め図-5に示した。また別 に測定した不揮発分と比重との関倸より, 塗膜の比重の 経時変化を求め 図-6に示した。ただしこの時の付着直 後の塗膜厚はいずれも $78 \mu$ とした。

また膜厚 $\left(x_{t}\right)$ の経時変化は塗膜重量 $\left(W_{t}\right)$ と塗布面 積 $(S)$ 技よび比重 $\left(\rho_{t}\right)$ から次式により求めた。

$$
x_{t}=\frac{W_{t}}{\rho_{t} \cdot S}
$$

式( 3 )上り求めた膜厚の時間変化を図-7 に示した。

見掛け粘度の時間変化は, 粘度が濃度とズリ速度の及

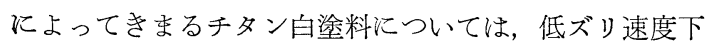
$\left(D=0.55 \mathrm{sec}^{-1}\right)$ での濃度と見掛怗度の関係をあらか じめ求めて扣き, 塗膜濃度の経時变化から見掛け粘度の 時間変化を求めた。その結果を図-8 に示した。

まて濃度とズリ速度のみでは見掛け粘度がきまらず， チキソトロピー性を示すアゾ系黄塗料については, スタ ーラーにより $2,000 \mathrm{rpm}$ の回転速度で数分間かくはん後, 静置時間を変兄て粘度の回復性を調べ, 濃度の異なる試 料について測定した結果を図-9に示した。また図-9の 結果を静置時間をパラメーターとして, 見掛子粘度と塗 料の濃度との関係にプロットしな掞した結果を図-10に 示した。図-5 の塗膜の不揮発分の変化と図-10 のチキ ソトロピールよる見掛讨粘度の回復変化とから，アゾ系

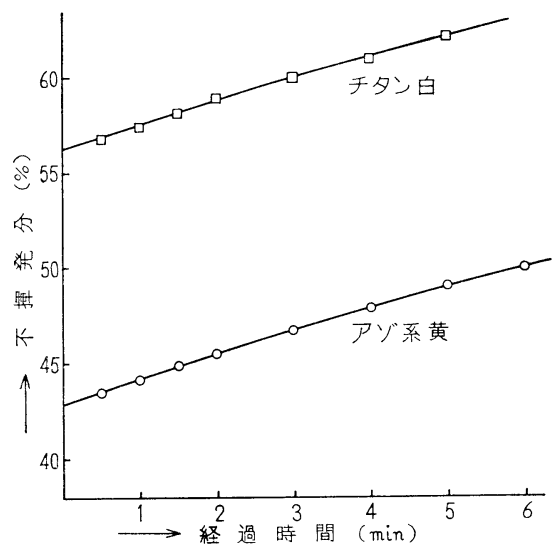

図-5フタル酸樹脂エナメル塗膜の不揮発 分の経時变化 (温度 $20^{\circ} \mathrm{C}$ )

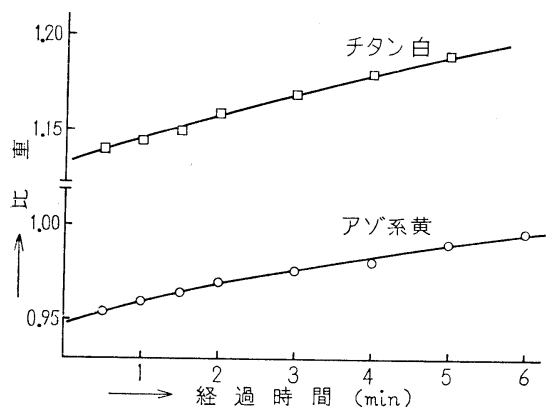

図-6 フタル酸樹脂エナメル塗膜の比重の 経時変化 (温度 $20^{\circ} \mathrm{C}$ )

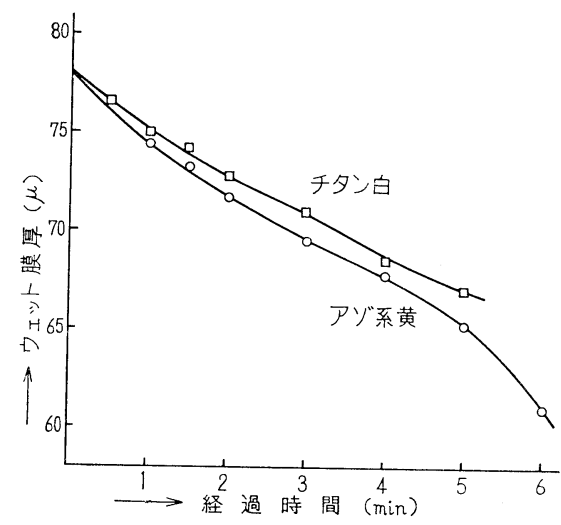

図-7 フタル酸樹脂エナメル塗膜のウェット 膜厚の経時变化 (温度 $20^{\circ} \mathrm{C}$ )

黄塗料の吹付ヶ後の塗膜の粘度变化を求め図-11 に示し た。

図-6, 図-7, 図-8 扣よび図-11 の結果より, 塗装後 $\mathrm{t}$ 分後の比重 $\left(\rho_{t}\right)$, 膜厚 $\left(x_{t}\right)$, 見掛け粘度 $\left(\eta_{t}\right)$ を求め, 式(2) に代入してその時のタルミ速度 $V_{t}$ を計算し, 塗 装直後から乾燥までの $V_{t}$ を時間の関数として求めた結 


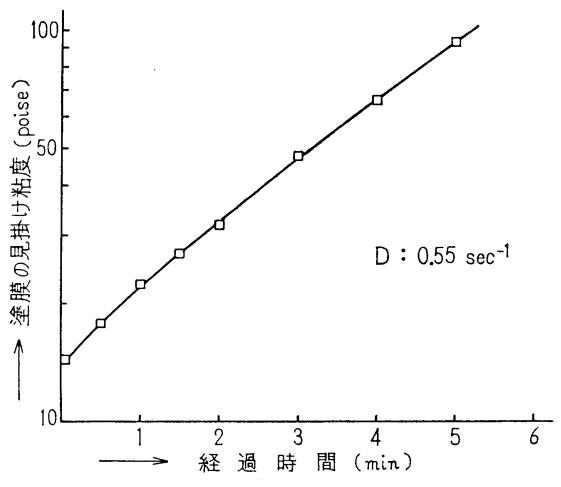

図-8 フタル酸樹脂エナメル・チタン白塗膜 粘度の経時变化 (温度 $20^{\circ} \mathrm{C}$ )

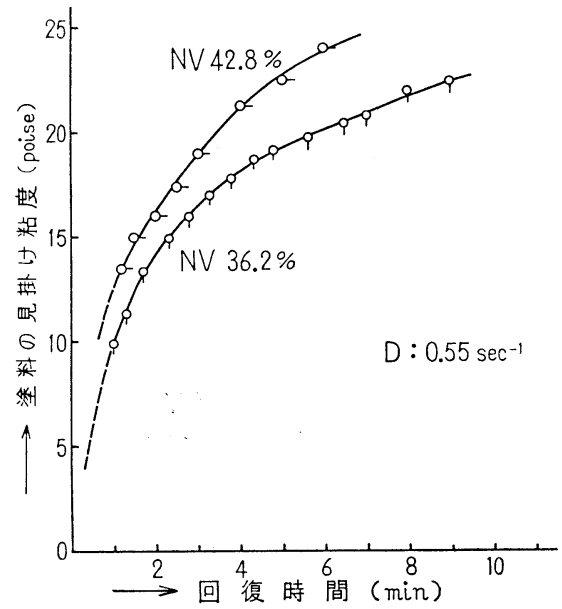

図-9 フタル酸樹脂エナメル・アゾ系黄の 粘度の回復性 (温度 $20^{\circ} \mathrm{C}$ )

果を図-12 に示した。図中，グラフ上の各点は，ある瞬 時のタルミの速度を表わしている。グラフを時間に関し て積分すれば，塗装直後から乾燥するまでのタルミの距 離を求めることがでさる。

塗装直後のウェット膜厚を $78 \mu$ としたときのフタル 酸樹脂エナメルチタン白和よびアり゙系黄塗料のタルミの 距離を求めた結果を表-4 に示した。この結果より，塗 膜表面のタルミ距離はチタン白塗料が $3 \mathrm{~mm}$ であるのに 対し，アゾ系黄塗料は $4.7 \mathrm{~mm}$ となってタルミやすい ことを示した。

$4 \cdot 5$ タルミの理論式による計算值と実験結果との比 較

以上，塗料間のタルミの難易を比較するために，いく つかの方法による実験と理論式による計算とを試みた。 この結果，吹付ヶ塗装した場合でも，未塗装部分への夕

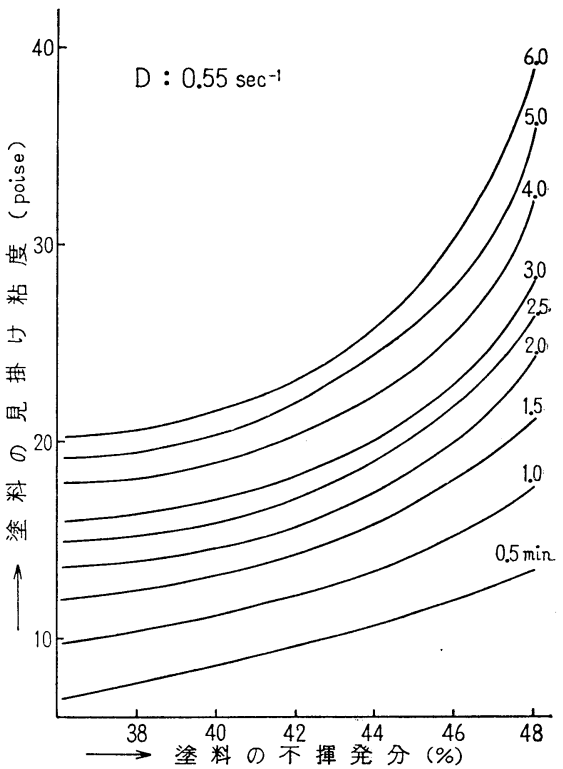

図-10 フタル酸樹脂エナメル・アゾ系黄の粘 度の回復性

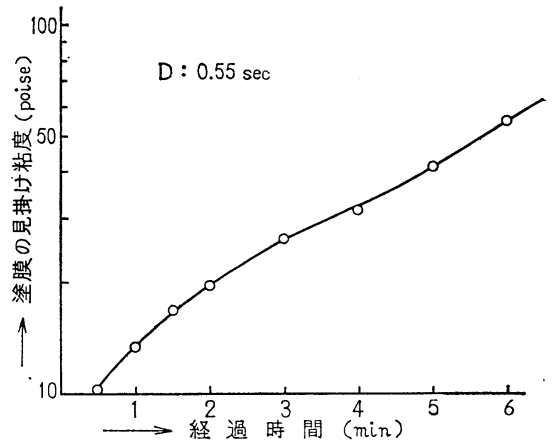

図-11 フタル酸樹脂エナメル・アゾ系黄塗膜 粘度の経時変化 (温度 $20^{\circ} \mathrm{C}$ )

表-4 塗膜タルミ距離計算結果

\begin{tabular}{|c|c|c|c|}
\hline 料 & 塗り膜厚 & 不揮発分 & $\begin{array}{l}\text { 塗膜タル } \\
\text { 距離 }\end{array}$ \\
\hline チタン白 & $78 \mu$ & $56.9 \%$ & $3.0 \mathrm{~mm}$ \\
\hline アゾ系黄 & 78 & 42.8 & 4.7 \\
\hline
\end{tabular}

ルミを見る方法や，アプリケーターによるタルミ試験法: では，チキソトロピー性の少ないチタン白やベンガラの 塗料はタルミが多く, アゾ系黄やフタロシアニンブルー 顔料の塗料が流れにくかった。一方，吹付ケによる塗装 面内でのタルミを比較する方法では, 前者とは逆で, チ タン白やベンガラの塗料はタルミが少なく，アゾ系黄や フタロシアニンブルーの塗料はタルミが多かった。

このように試験法の違いによりタルミの難易の結果が 


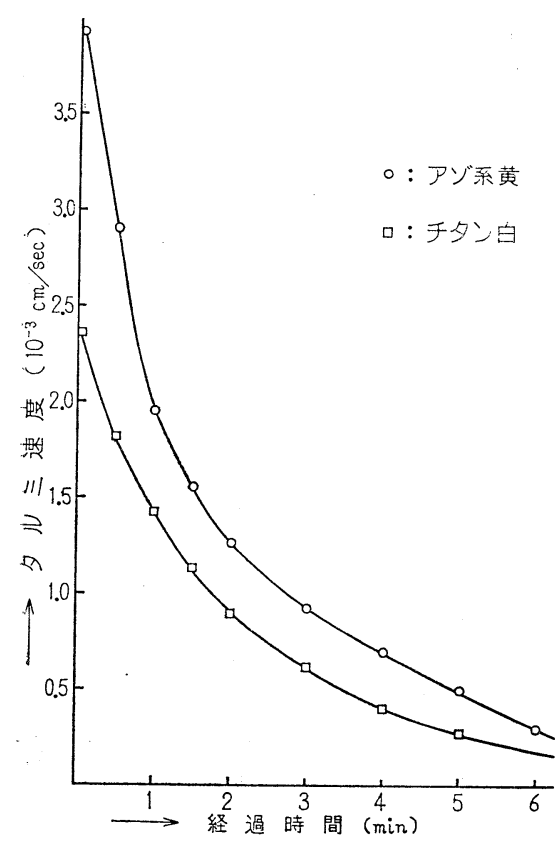

図-12 フタル酸樹脂エナメル塗膜のタルミ 速度の経時変化 (温度 $20^{\circ} \mathrm{C}$ )

逆となる原因は, 未塗装部分への流れ出しによりタルミ を判定する前者の方法では，新しい面を湿潤するための 仕事が必要となるため塗料がいったん塗膜下端にたる り，したがって，流下し始めるまでにチキソトロピーに よる構造回復があり，見掛怗度が上昇する。このため チキソトロピー性を有するアゾ系黄やフタロシアニンブ ルー塗料の方がタルミが少ない結果となった。

一方塗装面内でのタルミを調べる後者の方法では, 末 端効果よりも部分的な膜厚の違いによる流下速度の違い 坊ってできるタルミをみるため, チキソトロピーによ る構造回復と見掛忊粘度の上昇は影響が少なく,むしろ 吹付ヶ時の高いズリ速度下での粘度低下の方が影響が大 きい。このためアり゙系黄やフタロシアニンブルー塗料 は, 付着直後の見掛怗㪝が著しく小さく, タルミやす くなり, チタン白やベンガラの塗料はタルミが少ない結 果となった。
また，理論式から計算により求めたタルミの難易は， 塗装面でのタルミ試験の結果と一致し, テキソトロピー 性のあるアゾ系黄塗料の方がチタン白塗料に比ベタルミ やすかった。理論計算ではタマリの現象は考慮せず，塗 装直後から流れが始まったとして計算した。

実際の吹付ヶ塗装に打けるタルミ現象は, 末端効果よ りも部分的な膜厚の違いによる流下速度の違いによって さらに膜厚差が大きくなり，タルミが目立つことにな る。このような状態での試験法は後者の塗装面内でのタ ルミ試験でなければならない。

以上のように, 流動的性質が著しく異なる試料い吹付 ケ塗装に掠けるタルミの試験を，一般的なアプリケータ 一式の試験法で判定することは正しくない。また, 吹付 ケ法による試験でも, 未塗装部分へのタルミ試験から, 実際に起こるタルミを判定することも正しい方法とはい えない。

\section{文献}

1) R. J. Blackinton, Off. Dig., 25, 205 (1953)

2) W.K.Asbeck, Off. Dig., 33, 65 (1961)

3) T.C.Patton, Off. Dig., 29, 10 (1957)

4) W. W. Reynolds, Paint \& Varnish Production, 48, Aug. 31 (1958)

5) H.E.Hancock, Off. Dig., 29, 1086 (1957)

6) D. J. Doherty, \& R. Hurd, J. Oil \& Color Chem. Assoc., 41, 42 (1958)

\section{（後記）}

日本国有鉄道では“車両用塗料の規格ならびに試験方 法”を改制することを目的にして，昭和 $40 \cdot 41$ 年の 2 年度にわたって部外研究委託を日本鉄道技術協会を通じ 日本鉄道車両工業協会に対して行なった。当色材協会か らも桑田会長 (研究委員会会長) をはじめとして数名が 研究委員として参加し研究推進に協力した。本誌に発表 されている 3 編の報文「吹付ケ塗装に怙ける塗料の流出 量」, 「色判定方法の客観化について」,「吹付ヶ塗りに拉 けるタルミ」は上記研究の成果の一部でめって，特に国 鉄当局の承認を得て揭載したものである。（編集委員会） 